\title{
Św. Jan Chryzostom, VII Homilia w cyklu Homilii do Listu do Filipian
}

(In epistulam ad Philippenses argumentum et homiliae 7, CPG 4432)

\section{Wstęp}

\subsection{Miejsce i czas powstania}

Pod koniec IV wieku Chryzostom przystąpił do systematycznego wyjaśniania listów świętego Pawła, wygłaszając kilka związanych z nimi cykli. Podobno najwcześniej, bo już na przełomie wiosny i lata $399 \mathrm{roku}^{1}$, stworzył piętnaście homilii na temat Listu do Filipian ${ }^{2}$. W jednym z najnowszych i najbardziej kompletnych przekładów homilii Chryzostoma ${ }^{3}$ dotyczących Listu do Filipian pojawiła się hipoteza, że jakkolwiek teksty te rzeczywiście uważane są za pierwszą próbę wyjaśniania listów Pawłowych, trudno orzekać o ich integralności - nie ma bowiem żadnych dowodów, które pozwalają ustalić, że Jan Złotousty stworzył wszystkie homilie $\mathrm{z}$ serii $\mathrm{w}$ jednym czasie $^{4}$. Badania dotyczące pozostałych zbiorów komentarzy do listów św. Pawła jednoznacznie wskazują, że Chryzostom tworzył je partiami. Homilie $2001,145$.

J. N. D Kelly, Złote usta. Jan Chryzostom-asceta, biskup, kaznodzieja, Bydgoszcz

2 Niektórzy uczeni w zakres homilii wliczają także poprzedzające je hypothesis, które z uwagi na swój homiletyczny charakter wpisuje się we wspomniany cykl - można zatem przyjąć, że zbiór liczy 16 homilii. Por. Ioannis Chrysostomi interpretatio omnium epistularum Paulinarum, t. 5, red. F. Field, Oxford 1854-1862, 1-171 (tekst), 499-530 (przypisy).

3 P. Allen, John Chrysostom, Homilies on Philippians, Writings from the GrecoRoman World, Atlanta 2013.

4 W. Mayer - P. Allen, John Chrysostom, w: The Early Church Fathers, London 2000, 12 (wstęp). 
do Listu do Kolosan powstawały częściowo, zarówno w okresie jego przebywania w Konstantynopolu, jaki i Antiochii ${ }^{5}$. Problematyczna wydaje się przy tym kwestia braku spójności pomiędzy treścią poszczególnych homilii, jedynie w niektórych zauważyć można spójność wywodu czy wyraźny związek pomiędzy zakończeniem jednej a początkiem kolejnej części ${ }^{6}$. Kolejna trudność to różnica w stylu uważanym skądinąd za jeszcze niedostatecznie wyrobiony, którym Chryzostom posługuje się w konkretnych homiliach cyklu. Próby ustalenia dat wygłoszenia powyższych mów mogą opierać się jednak na wzmiankach w homiliach dotyczących ówczesnych sytuacji społeczno-politycznej będących dygresją do sposobu panowania danego władcy, choć żadna z nich nie daje wystarczającej pewności ${ }^{7}$. Dowodem potwierdzającym hipotezę odnośnie do czasu powstania homilii na temat Listu do Filipian może być komentarz zawarty w jednej z nich będący aluzją do despotycznych rządów Eutropiosa i stanowiący jednocześnie poparcie upadku potężnego zwierzchnika cesarskiego domu, który miał miejsce właśnie latem 399 roku. Jan Złotousty pisze: ,[...] Podczas gdy wielu biedaków wiedzie życie wolne od obaw, losy ministrów, ludzi bogatych i arystokratów są znacznie bardziej godne pożałowania niż dola przestępcy, bandyty i grabieżcy grobów"8. Ostatecznie większość badaczy, po wnikliwej analizie ostatniej homilii z cyklu Listu do Filipian, przychyla się do ich antiocheńskiej proweniencji ${ }^{9}$.

\subsection{Tematyka i struktura VII homilii $z$ cyklu homilii do Listu do Filipian}

Chryzostom jako wybitny uczeń Libaniosa otrzymał od swego mistrza doskonałą podstawę z zakresu wiedzy retorycznej. Zachowując swo-

5 P. Allen - W. Mayer, Chrysostom and the Preaching of Homilies in Series: A New Approach to the Twelve Homilies In epistulam ad Colossenses (CPG 4433), ,, Orientalia christiana periodica" 60 (1994) 274-275.

6 Por. G. Bady, La tradition des oeuvres de Jean Chrysostome, entre transmission et transformation, „Revue des Études Byzantines” 68 (2010) 149-63, 159-63; P. Allen, Chrysostom and the Preaching, s. 278-79.

7 Uczeni badają także kwestie autentyczności znajdujących się w homiliach komentarzy. Większość z nich pozostaje przedmiotem sporu. Por. D. Barnes, Constantine and Eusebius, Cambridge-Harvard 1981, 220-221; W. Mayer, The Homilies of St John Chrysostom - Provenance, Reshaping the Foundations, Rome 2005, 235-273.

8 Fragment tej homilii przywołuje we wspomnianej monografii J.N.D. Kelly, dokładnie w rozdziale dotyczącym działalności Chryzostoma w Konstantynopolu. Por. Kelly, Złote usta, s. 146.

9 Allen - Mayer, Chrysostom and the Preaching, s. 274-275. 
je podstawowe założenie, jakim było komentowanie danego fragmentu Pisma Świętego, omawiana homilia Jana Złotoustego jest także przykładem wystąpienia spełniającego podstawowe wytyczne powstałej w antyku teorii mów. W obrębie poszczególnych części homilii odnaleźć można struktury i świadomie używane środki retoryczne potwierdzające warsztat mówcy. Chryzostom, rozpoczynając swoje wystąpienie, posługuje się typowym - dla doradczego rodzaju mowy - wstępem (proemium), którego jedynym celem jest przygotowanie publiczności w taki sposób, aby była skłonna wysłuchać dalszej części mowy ${ }^{10}$. Aby pozyskać uwagę słuchaczy, Chryzostom posługuje się słownictwem sugerującym, że przedmiot sprawy jest niezwykle istotny - przedstawia metaforę, w której Boski Logos porównany jest do miecza obosiecznego, który jest w stanie pokonać nawet dziesięciotysięczną falangę. Następnie używa zwrotów w trybie rozkazującym, chcąc nakłonić słuchaczy do uważnego przyswajania treści, np. „uważajcie i zbudźcie się”. W początkowej części homilii odnaleźć można dwie struktury, w których Chryzostom zestawia słowa Jezusa i św. Piotra wzywających do pokory - obydwa przykłady poparte są przykładami z Pisma Świętego. Wydaje się, że poprzez przedstawienie tych zachęt mówca stara się określić główny temat swojej homilii. Struktura zachęty wydaje się przemyślana i przejrzysta, zbudowana na zasadzie analogicznych konstrukcji.

Teza: Chrystus zachęcał do pokory, podając za przykład siebie, Ojca i proroków.

„Nasz Pan Jezus Chrystus, zachęcając swych uczniów do czynienia wielkich dzieł, podaje za przykład siebie, Ojca, a także proroków, jak wtedy, gdy mówił: [...]”.

Exemplum z Pisma Świętego potwierdzające tezę.

„«Tak bowiem czynili z prorokami, którzy byli przed wami» i znowu: «Jeżeli mnie prześladowali, to i was prześladować będą», a także: «Uczcie się ode mnie, bo jestem cichy» i znowu: «Bądźcie miłosierni, jak wasz Ojciec w niebiosach».

Teza: Paweł zachęcał do pokory, podając za przykład Chrystusa.

„To samo czyni błogosławiony Paweł, zachęcając [Filipian] do pokory, podaje za wzór Chrystusa. Postępuje tak nie tylko tu, przemawia w podobny sposób, kiedy rozprawia o miłości względem ubogich: [...]”.

Exemplum z Pisma Świętego, potwierdzające tezę.

„Znacie przecież łaskę Pana naszego Jezusa Chrystusa, który będąc bogaty, dla nas stał się ubogim. Wreszcie dodaje: «to dążenie niech was pokrzepia, ono też było w Jezusie Chrystusie, On, istniejąc w postaci Bożej, wie-

10 H. Lausberg, Retoryka literacka. Podstawy wiedzy o literaturze, Bydgoszcz 2002, 157. 
dział, że Jego bycie równym Bogu nie jest zawłaszczeniem, ale [jednak] ogołocił samego siebie, przyjąwszy postać sługi, stawszy się podobnym do ludzi»».

We wstępie pojawiają się także dwie metafory. Pierwsza z nich, wcześniej wspomniana, zaczerpnięta została z Biblii (Prz 5,4; Syr 21,3; Hbr 4,12; Ap 1,16; 2,12) i stanowi porównanie działania Logosu do obosiecznego miecza. Kolejna przedstawia wyścig rydwanów, w którym jeden z jeźdźców pokonuje wszystkich przeciwników. Obydwie metafory obrazują działanie Pisma Świętego w walce z herezjami. Warto zaznaczyć, że mówca powraca do ostatniego porównania także w kolejnej części mowy - obraz ten stanowi zatem rodzaj klamry, która scala wszystkie zawarte w homilii treści dotyczące herezji. Część wstępną kończy Chryzostom za pomocą zwrotu do audytorium w celu ustalenia sposobu przedstawiania herezji. Jest to wprowadzenie do wywodu, który mówca ma zamiar kontynuować w ramach kolejnych części homilii, w retoryce określane jest terminem transitus ${ }^{11}$.

Mówca podejmuje w obrębie homilii trzy zagadnienia. Część główną swego wystąpienia rozpoczyna od przywołania poszczególnych heretyków, którzy podważają bóstwo Chrystusa. Podejmując polemikę z reprezentowanymi przez nich założeniami, Chryzostom podważa je, posługując się exemplum odwołującym się do autorytetu (auctoritas) ${ }^{12}$, którym jest Pismo Święte. Przywołuje tu m.in. fragmenty hymnu o kenozie będącego podstawą do homilii. Celem omówienia pierwszego zagadnienia jest więc obalenie teorii, które mogłyby świadczyć przeciwko pokorze Chrystusa. Złotousty twierdzi, że zgadzając się na umniejszenie Chrystusa względem Boga, nie można byłoby mówić o pokorze Syna. Gdyby Chrystus (jak sądzą heretycy) nie był równy swemu Ojcu, jego postawa uniżenia ukazana w hymnie o kenozie nie byłaby przykładem pokory. Tu warto zaznaczyć, że Chryzostom, upatrując największe niebezpieczeństwo w poglądach Ariusza i jego zwolenników, najwięcej uwagi poświęca podważeniu założeń jego herezji.

Kolejnym tematem poruszanym przez Chryzostoma jest charakterystyka pokory. Autor przywołuje jej definicję, tłumacząc ją następnie za pomocą przykładów, które nawiązują do codzienności. Prostotę myślenia oraz uniżenie, które stanowią według Chryzostoma sedno pokory, wyjaśnia dzięki przywołaniu kontrastujących ze sobą postaci. Przedstawia człowieka, który ma predyspozycje do tego, aby myśleć o rzeczach wzniosłych, zestawiając go z człowiekiem prostym. Zestawia także króla i podwładnego. Zaznacza przy tym, że rezygnacja

11 Lausberg, Retoryka literacka, s. 204.

12 Lausberg, Retoryka literacka, s. 260. 
z tego, co znajduje się w obrębie czyichś możliwości, jest objawem uniżenia i pokory, w przeciwnym wypadku powstrzymanie się od wyżej wspomnianych nie jest odzwierciedleniem pokornej postawy. Głównym celem przedstawienia tego zagadnienia jest próba uświadomienia audytorium, że pokorę można osiągnąć jedynie poprzez wyrzeczenie czy rezygnację z pożądania wysokich stanowisk, które są w zasięgu danego człowieka.

Następnie, po omówieniu zagadnienia pokory, Chryzostom powraca do problemu heretyków w celu podsumowania i ostatecznego rozprawienia się z ich argumentami. Autor posługuje się tutaj ewangeliczną metaforą dotycząca „,boskiego nasienia” uzdrawiającego ziemię - po wykorzenieniu cierni, które symbolizują herezje, ziemia „przyniesie owoc obfity”. Należy w tym fragmencie zwrócić uwagę na niezwykłą spójność wywodu Chryzostoma, który podejmując ponownie problem herezji, tworzy odwołanie do wcześniejszego zagadnienia związanego z zachętą do pokory. Kolejna część homilii, poruszająca trzecie zagadnienie, stanowi przestrogę przed szatanem i chciwością oraz odwróceniem się od Boga. Chryzostom przedstawia wizję życia człowieka, który odrzucił Boga i jego naukę. W celu potwierdzenia swoich słów przywołuje dłuższy fragment z Księgi Izajasza dotyczący winnicy, która nie wydała owoców. Po raz kolejny posługuje się argumentacją przez odwołanie do autorytetu Pisma Świętego. Następnie przechodzi do ostrzeżenia przed chciwością. Podając przykład Judasza, Chryzostom ukazuje zgubne skutki chciwości. Mówca używa tu odwołania do konkretnej postaci. Przykład ten wpływa na świadomość słuchaczy, dla których omawiany problem staje się bardziej rzeczywisty. Jan Złotousty podaje najpierw przykład Judasza - człowieka zniewolonego przez chciwość, po czym kieruje do swych słuchaczy przestrogę przed jej zgubnym działaniem.

Chryzostom stosuje w swej homilii niezwykle zwięzłe zakończenie. Odnaleźć w nim można jedynie odwołanie się do poprzedniego zagadnienia przyjęcia pokornej postawy będącego nawołaniem do wiary w zmartwychwstanie. Widać tu zatem próbę powiększenia znaczenia wcześniej wspomnianych argumentów ${ }^{13}$ - wszystkie dotychczasowe zalecenia Chryzostoma mają prowadzić do czegoś o dużo większym znaczeniu, a mianowicie do wiary w zmartwychwstanie i osiągnięcia życia wiecznego. Ukazanie nadziei związanej z tym, że wszyscy z obecnych mają szanse je otrzymać, może być tutaj przykładem oddziaływania na emocje audytorium $^{14}$. Na końcu pojawia się także charakterystyczna dla homilii doksologia.

13 Lausberg, Retoryka literacka, s. 262.

14 Lausberg, Retoryka literacka, s. 262. 
Posłużenie się krótkim zakończeniem pozawala Chryzostomowi na zwięzłe i dosadne podsumowanie zawartych w poprzednich częściach treści. Mimo że autor nie streszcza kolejno przywołanych zagadnień, przedstawia fundamentalny warunek osiągnięcia wiecznego szczęścia przez chrześcijanina. Podkreśla tym samym, że spełnienie powyższego pociągnie za sobą wierność i uznanie dla spraw poruszanych w obrębie całej homilii.

Warto zwrócić uwagę, że w obrębie poszczególnych części powielane są schematy konstruujące całą homilię. Zarówno we wstępie, części głównej, jak i zakończeniu Chryzostom posługuje się określonymi strukturami złożonymi z przedstawionych tez oraz odpowiadającej im argumentacji w postaci cytatu z Pisma Świętego czy przykładu zaczerpniętego z codzienności. W każdej z wyszczególnionych wyżej części Jan Złotousty przywołuje dodatkowo metafory, aby zobrazować omawiany problem.

\section{Wydania tekstu}

Montfaucon B. de, Joannis Chrysostomi Opera, t. 13, Paris 1855, 1718-1738.

Migne P., Joannes Chrysostomus, Parisiis 1862, PG 62, 218-228.

\subsection{Przekłady nowożytne}

\section{Angielskie:}

Allen P., John Chrysostom, Homilies on Paul's Letter to the Philippians, Atlanta 2013, 113-169.

Cotton C.W., The Homilies of S. John Chrysostom, Archbishop of Constantinople, on the Epistles of St. Paul the Apostle to the Philippians, Colossians, and Thessalonians, Oxford 1843, 87-135.

\section{Francuskie:}

Bareille J.A., Ouvres complètes de St. Jean Chrysostome: Traduction nouvelle, Paris 1872 (vol. XVIII). 
Niemieckie:

Stoderl W., Des hl. Kirchenlehrers Johannes Chrysostomus, Erzbischofs von Konstantinopel, Kommentar zu den Briefen des hl. Paulus an die Philipper und Kolosser, Munich 1924.

\section{Bibliografia}

Allen P. - Neil B. - Mayer W., Preaching Poverty in Late Antiquity: Perceptions and Realities, Leipzig 2009.

Allen P. - Mayer W., Chrysostom and the Preaching of Homilies in Series: A New Approach to the Twelve Homilies In epistulam ad Colossenses (CPG 4433), „Orientalia christiana periodica" 60 (1994) 274-275.

Allen P. - Mayer W., Chrysostom and the Preaching of Homilies in Series: A Re-Examination of the Fifteen Homilies in Epistulam ad Philippenses (CPG 4432), „Vigiliae Christianae" 49 (1995) z. 3, 270-289.

Amirav H., The rhetorical expression of exegesis: The case of John Chrysostom, w: Giovanni Crisostomo: Oriente e Occidente tra IV e V secolo, Roma 2004.

Baur Ch., John Chrysostom and His Time, Westminster 1959-1960.

Preacher and Audience: Studies in Early Christian and Byzantine Homiletics. A New History of the Sermon, red. C.B. Cunningham - P. Allen, Leiden 1998.

Illert M., Johannes Chrysostomus und das antiochenisch-syrische Mönchtum: Studien zu Theologie, Rhetorik und Kirchenpolitik im antiochenischen Schrifttum des Johannes Chrysostomus, Zürich 2000.

Jankowski A., Hymny o pokorze Chrystusa, Appendix, w: Listy więzienne Świętego Pawła, wstęp, przekład, komentarz, Poznań 1962.

Kelly J.N.D., Złote usta. Jan Chryzostom - asceta, biskup, kaznodzieja, Bydgoszcz 2001.

Kelly J.N.D., Początki doktryny chrześcijańskiej, Warszawa 1988.

Lausberg H., Retoryka literacka. Podstawy wiedzy o literaturze, Bydgoszcz 2002.

Mayer W. - Allen P., John Chrysostom. The Early Church Fathers, London 2000.

Mayer W., The Homilies of St John Chrysostom - Provenance, Reshaping the Foundations, Rome 2005.

Mitchell M.M., The Heavenly Trumpet: John Chrysostom and the Art of Pauline Interpretation, Louisville 2002. 


\section{Przeklad ${ }^{15}$}

„To dążenie niech was ożywia; ono też było w Chrystusie Jezusie. On, istniejąc w postaci Bożej, wiedział, że Jego bycie równym Bogu nie jest zawłaszczeniem, ale [jednak] ogołocił samego siebie, przyjąwszy postać sługi, stawszy się podobnym do ludzi. A w zewnętrznym przejawie, uznany za człowieka, uniżył samego siebie, stawszy się posłusznym aż do śmierci - i to śmierci krzyżowej" (Flp 2,5-8) ${ }^{16}$.

Nasz Pan Jezus Chrystus, zachęcając swych uczniów do czynienia wielkich dzieł, podaje za przykład siebie, Ojca, a także proroków, wtedy gdy mówił: „tak bowiem czynili z prorokami, którzy byli przed wami” (Mt $5,12)$ i znowu: „Jeżeli mnie prześladowali, to i was prześladować będą” (J 15,20), a także: „Uczcie się ode mnie, bo jestem cichy” (Mt 11,29) i dalej: „Bądźcie miłosierni, jak wasz Ojciec w niebiosach” (Łk 6,36). To samo czyni błogosławiony Paweł - zachęcając [Filipian] do pokory, podaje za wzór ${ }^{17}$ Chrystusa. Postępuje tak nie tylko w tej kwestii. Przemawia w podobny sposób, kiedy naucza o miłości względem ubogich: „Znacie przecież łaskę Pana naszego Jezusa Chrystusa, który będąc bogaty, dla nas stał się ubogim" (2Kor 8,9). Nic tak nie pobudza pięknej i filozoficznej duszy do czynienia dobra jak świadomość, że przez to upodabnia się do Boga. Co może być równe tej zachęcie? Nic. Zapewne wie o tym także Paweł, kiedy namawiając do pokory, najpierw wzywa poprzez prośby i błagania, a następnie zawstydzając, mówi: „ponieważ trwacie w jednym duchu wspomina - to jest dla nich zapowiedzią zagłady, dla was - zbawienia". Wreszcie dodaje: „to dążenie niech was pokrzepia, ono też było w Jezusie Chrystusie, On, istniejąc w postaci Boga, wiedział, że Jego bycie równym Bogu nie jest zawłaszczeniem, ale [jednak] ogołocił samego siebie, przyjąwszy postać sługi, stawszy się podobnym do ludzi”. Uważajcie, błagam i zbudźcie się ${ }^{18}$. Słowa Ducha Świętego są jak ostry miecz obosieczny, który, gdziekolwiek upadnie, chociażby pośród dziesięciotysięcznej falangi,

15 Tłum. według wydania: P. Migne, Patrologiae Graecae Tomus LXII. S. Joannes Chrysostomus. w: Patrologiae cursus completus, Parisiis 1862, 218-228.

16 Przekład powyższego cytatu, będącego podstawą komentowanego tekstu, z uwagi na trudności interpretacyjne oraz rozbieżności w ramach poszczególnych dostępnych tłumaczeń, pochodzi od tłumaczki tekstu. Pozostałe cytaty z Pisma Świętego podane są za: Pismo Święte Starego i Nowego Testamentu, Poznań-Warszawa 1980 (Biblia Tysiąclecia).

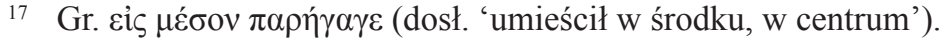

18 Kwestia interakcji pomiędzy kaznodzieją a publicznością poruszona została m.in. w pozycjach: M.B. Cunningham - P. Allen, Preacher and Audience: Studies in Early Christian and Byzantine Homiletics, w: A New History of the Sermon 1, Leiden-Brill 1998. 
z łatwością przecina wszystko na wskroś, ponieważ jest ostry z obydwu stron, i nic nie może powstrzymać jego ostrza. Poprzez te słowa całkowicie obalił zwolenników Ariusza z Aleksandrii ${ }^{19}$, Pawła z Samosaty ${ }^{20}$, Marcelego z Galacji ${ }^{21}$, Sabeliusza z Libii ${ }^{22}$, Marcjona z Pontu ${ }^{23}$, Walentyna ${ }^{24}$ i Manesa ${ }^{25}$, Apolinarego z Laodycei ${ }^{26}$, a także Fotyna ${ }^{27}$ i Sofroniusza ${ }^{28}$ oraz wszystkie pozostałe herezje. Zbudźcie się, abyście zobaczyli ten wspaniały widok, jak od jednego ciosu upadło tyle oddziałów, nie pozwólcie, aby umknęło wam tak niezwykłe widowisko. Ponieważ kiedy rydwany biorą udział w wyścigach, nie ma niczego przyjemniejszego, niż kiedy jeden z nich, pędząc, przewraca wszystkie konie wraz z jeźdźcami, a wywróciwszy wszystkich, sam zmierza do celu i do mety wśród oklasków i okrzyków wznoszących się do nieba. Ta przyjemność przebywania wśród oklasków sprawia, że ów jeździec czuje się, jakby przedzierał się przez cały stadion na skrzydlatym koniu. O ile więc przyjemniej jest być tutaj, gdy z łaski Bożej możemy obalić stada i diabelskie kuźnie słów ${ }^{29}$ straszliwych herezji

19 W niniejszej homilii Chryzostom będzie odnosił się do poglądu subordynacjonizmu głoszonego przez Ariusza, który potępiony został na Soborze Nicejskim w 325 roku.

20 Paweł z Samosaty (ok. 200-273) najprawdopodobniej związany z nurtem monarchianizmu, opowiadał się za chrystologią adopcjanizmu zakładającą, że Chrystus został przysposobiony przez Ojca po narodzinach.

21 Marceli z Galacji uczestniczył w Soborze w Nicei w 325 roku, został oskarżony o głoszenie sabelianizmu. Por. przypis poniżej.

22 Sabeliusz z Libii - od jego imienia pochodzi nazwa wspomnianej wyżej doktryny zaprzeczającej istnieniu hipostazy Trójcy Świętej.

23 Marcjon z Pontu (ok. 100-160) odrzucał Stary Testament, nie uznawał także części ksiąg Nowego Testamentu za kanoniczne, podobnie jak gnostycy sprzeciwiał się małżeństwom i prokreacji, chcąc w ten sposób doprowadzić do zagłady świata stworzonego przez demiurga-tyrana.

24 Walentyn - postać nie do końca identyfikowalna, najprawdopodobniej jeden z egipskich wyznawców gnostycyzmu, żył w II wieku.

25 Manes (ur. 216) - ojciec manicheizmu, systemu religijnego będącego syntezą zoroastryzmu, buddyzmu i chrześcijaństwa. Postawę poglądową manicheizmu stanowił dualizm.

26 Apollinary z Laodycei (310-390) - autor doktryny zwanej apolinaryzmem kwestionującej kompletność natury Chrystusa. Apolinary zakładał, że natura Chrystusa nie posiadała duszy rozumnej.

27 Fotyn, uczeń Marcelego z Ancyry, biskup Sirmium, kilkakrotnie potępiany, negował byt osobowy Chrystusa. Nie zachowało się żadne z jego pism.

28 Sofroniusz - jego nauki zostały potępione podczas synodu w Konstantynopolu w 360 roku. Zachowało się niewiele informacji na jego temat.

29 Gr. દ̇ $\rho \gamma \alpha \sigma \tau \eta ́ p ı \alpha$ - wyrażenie ,kuźnie słów” było często używane przez Libaniusza, długoletniego nauczyciela i mistrza Jana Chyzostoma. 
wraz z ich jeźdźcami? Lecz najpierw - jeśli wam to odpowiada - ułóżmy herezje w odpowiednim porządku.

Czy chcecie uporządkować je [herezje] ze względu na stopień bezbożności ${ }^{30}$ czy według chronologii? Uczyńmy to według czasu powstania, trudne byłoby zestawienie $\mathrm{z}$ uwagi na bezbożnośćc ${ }^{31}$. A zatem pierwszy pojawił się Sabeliusz, później wystąpił Libiusz. Co on mówi? Że Ojciec, Syn i Duch Święty to imiona odnoszące się do jednej osoby. Marcjon z Pontu twierdzi, że Bóg, stwórca wszystkiego, nie jest dobry ani też nie jest Ojcem dobrego Chrystusa, lecz że jest to jakiś inny sprawiedliwy. Mówi także, że Syn nie przyjął dla nas ciała. Marceli, Fotyn i Sofroniusz twierdzą, że Logos jest działaniem, które zamieszkało w potomku Dawida, nie jest natomiast bytem osobowym ${ }^{32}$. Ariusz potwierdził istnienie Syna, lecz tylko w słowie. Uważał, że jest stworzeniem dużo niższym od Ojca. Inni natomiast twierdzą, że Syn nie ma duszy ${ }^{33}$. Widzisz stojące rydwany? Spostrzegasz zapewne ich upadek, jak powala wszystkich jednym uderzeniem. W jaki sposób? „To dążenie niech was pokrzepia - powiada - ono też było w Jezusie Chrystusie. On to, istniejąc w postaci Boga, wiedział, że Jego bycie równym Bogu nie jest zawłaszczeniem”. I tak upadł Paweł z Samosat, Marceli i Sabeliusz. [Paweł] mówi: „Istniejąc w postaci Bożej”. Jeśli w postaci, dlaczego twierdzisz o niegodziwcze [heretyku], że bierze swój początek z Maryi i że wcześniej nie istniał? Dlaczego znów mówisz, że był działaniem? [Paweł] mówi: ,istniejąc w postaci Bożej, przyjął postać sługi”. Powiedz mi, czy postać sługi to działanie sługi czy też natura sługi? Odpowiesz z pewnością, że natura sługi. Zatem i postać Boga jest naturą Boga, a nie energią. Spójrz, w ten sposób upadli Marceli z Galacji, Sofroniusz i Fotyn. Przyjrzyj się Sabeliuszowi. Jest napisane: „wiedział, że Jego bycie równym Bogu nie jest zawłaszczeniem”. Nie mówi się o jednej osobie, że jest równa. To, co jest równe, jest równe czemuś. Widzisz hipostazę dwóch osób, a nie tylko wymawiane, puste imiona, które nie odnoszą się do żadnych rzeczy? Usłyszałeś o przedwiecznym istnieniu Jednorodzonego? To wszystko, jeśli chodzi o nich.

Co natomiast powiemy o Ariuszu, który mówił, że Syn jest z innej substancji? Powiedz mi, co znaczy „,przyjął postać sługi”?. Oznacza to, że stał się człowiekiem, a więc stwierdzenie ,istniejąc w postaci Bożej” oznacza,

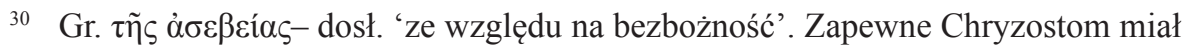
tu na myśli rodzaj, stopień niezgodności z ówczesnym nauczaniem Kościoła.

31 Przy poprzednim wymienianiu heretyków Chryzostom nie podawał ich chronologicznie, tu powraca zatem do układu według czasu powstania herezji.

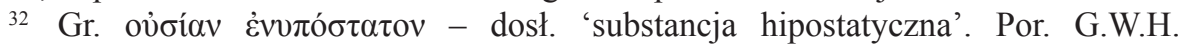
Lampe, A Patristic Greek Lexicon, Oxford 1969, 1454 (hasło: ov̉oía B6).

33 Chodzi o Apolinarego z Laodycei i jego wyznawców. 
że był Bogiem. Jedno i drugie jest nazwane postacią. Jeśli pierwsze jest prawdziwe, drugie także. „Postać sługi” oznacza człowieka z natury. A więc również ,postać Boga” oznacza Boga z natury. I nie tylko w tym względzie, lecz również jeśli chodzi o równość względem [Ojca], to zaświadcza [Paweł], podobnie jak Jan, że w żaden sposób [Syn] nie jest niższy od Ojca, mówi bowiem: ,wiedział, że Jego bycie równym Bogu nie jest zawłaszczeniem". Lecz jaki jest ich [heretyków] podstępny zamysł? Otóż oni twierdzą, że tymi słowami [Paweł] ukazuje sprzeczność, ponieważ mówi, że chociaż Jezus istniał „, postaci Boga, nie zawłaszczył sobie równości z Bogiem”. Twierdzą więc: „Skoro był Bogiem, jak mógł zawłaszczyć [to bycie]?". Czy to możliwe, że oni w ten sposób to zrozumieli? Czy ktoś może powiedzieć, że będąc człowiekiem, zawłaszczył sobie bycie człowiekiem? Czy bowiem ktoś może zawłaszczyć sobie bycie tym, kim jest? Nie - mówią - lecz że będąc Bogiem mniejszym, nie zawłaszczył sobie bycia na równi z Bogiem wspanialszym i większym. Jest zatem wielki i mały ${ }^{34}$ Bóg? Czy nie wprowadzacie greckich idei do nauczania Kościoła? U nich jest wielki i mały bóg. Czy tak jest także i u was - nie wiem. Nie znajdziecie tego w pismach, ponieważ fakt, że Bóg jest wielki, znajdziecie wszędzie, że jest mały - nigdzie. Jeśli [byłby] mały, jak mógłby być także Bogiem? Skoro nie można mówić o tym, że jest człowiek wielki i mały co do natury, lecz że każdy ma jedną naturę, a tym samym jeśli ktoś tej właśnie natury nie ma, nie jest człowiekiem - to jak może być Bóg wielki i mały, który nie ma boskiej natury? Ten, który jest mały, nie jest Bogiem. Wszędzie w Piśmie Świętym nazywany jest wielkim: „Wielki jest Pan - jak mówi Dawid - i godzien wszelkiej chwały" (Ps 48,1). Spójrz, mówi [on] także o Synu, wszędzie bowiem nazywał go Panem. I dalej: „Bo Ty jesteś wielki i działasz cuda, tylko Ty jesteś Bogiem” (Ps 86,10). I znowu: „Wielki jest Pan i wielka jest jego moc, a wielkość jego niezgłębiona" (Ps 48,2). Lecz to dotyczyło Ojca, Syn, jak mówi [heretyk], jest mały. Tak twierdzisz ty [heretyku], Pismo natomiast przeciwnie - w ten sam sposób mówi o Ojcu, jak i o Synu. Posłuchaj Pawła, który mówi: „oczekując błogosławionej nadziei i objawienia się chwały wielkiego Boga" (Tt 2,13). Lecz czy nie mówił o objawieniu Ojca? Aby bardziej tego dowieść, dodał - objawienie „wielkiego Boga”. Czy więc nie mówił tu o Ojcu? Bynajmniej, [mówił]. To zaś dodanie nie pomija [Jezusa], ponieważ [Paweł] powiedział: „I objawienia się chwały wielkiego Boga i Zbawiciela naszego Jezusa Chrystusa". Spójrz, Jezus także jest wielki. Dlaczego więc mówisz o wielkim i małym Bogu? Posłuchaj proroka, który nazywa go posłańcem wielkiej nowiny ${ }^{35}$.

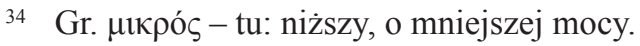

35 Por. Iz 9,5; 52,7 (LXX). 
Czy posłaniec wielkiej nowiny nie jest wielki? Czy potężny Bóg nie jest wielki, lecz mały?

Dlaczego więc mówią bezwstydni i zuchwali, że będąc mały, jest Bogiem? Wspominałem wielokrotnie, abyście się ich [heretyków] bardziej wystrzegali. Będąc małym Bogiem, jak mówią, nie mógł zawłaszczyć sobie bycia Bogiem wielkim. Zatem powiedz mi [heretyku], co to oznacza? Nie sądźcie tylko, że i ja tak uważam. Jeśli według nich był mały i posiadał o wiele mniej mocy niż Ojciec, jak mógł mieć możliwość zawłaszczenia sobie tego, aby być równym z Bogiem? Będąc niższym pod względem natury, nie mógł zawłaszczyć sobie bycia wielkim. Podobnie jak człowiek nie może być pod względem natury równy $z$ aniołem czy też koń, nawet gdyby chciał, nie może być pod względem natury równy człowiekowi. A poza tym zapytam tak: co Paweł zamierzał wykazać za pomocą tego przykładu? Z pewnością powiesz [heretyku], że chciał nakłonić Filipian do pokory. Dlaczego więc, powiedź mi, podawałby to za przykład? Nikt bowiem, kto pragnie nakłaniać do pokory, nie robi tego w ten sposób: „Bądź pokorny i myśl o sobie, że jesteś mniejszy niż tobie podobni, i ten bowiem, który był sługą, nie wzniósł się do godności Pana. A zatem, naśladuj go”. Ktoś może powiedzieć, że to nie jest pokora tylko głupota. Uczcie się, czym jest pokora, Wy, którzy macie diabelską pychę!

Czym więc jest pokora? Prostotą myślenia ${ }^{36}$. Prosty w myślach nie jest ten, który jest pokorny z konieczności, lecz ten, który sam siebie uniża. Wytłumaczę to jaśniej, słuchajcie uważnie. Kiedy ktoś ma możliwośćci aby myśleć w sposób wyniosły, jednak jest prosty w myślach, ten jest wówczas pokorny. Ten natomiast, który jest prosty w myślach, ponieważ nie ma możliwości, aby myśleć o sobie wzniośle, nie jest pokorny. Podobnie jeśli król podporządkowałby się podwładnemu, byłby pokorny, ponieważ odstąpił od swej wysokiej pozycji. Lecz jeśli podwładny uczyniłby podobnie, nie będzie pokorny, bo jakże? Nie zrezygnował ze swej wysokiej pozycji. Nie ma możliwości, aby ukazać pokorę w myśleniu, jeśli nie ma się władzy i możliwości, by móc uczynić inaczej. Bo jeśli bycie pokornym wypływa nie z chęci, lecz z konieczności, wówczas doskonałość nie pochodzi z woli, lecz z przymusu. $\mathrm{Z}$ tego powodu mówi się, że pokora to uniżenie myśli. Powiedz mi, czy jeśli ktoś nie ma możliwości, aby pozyskać czyjś majątek i pozostaje przy swoim, uważalibyśmy go za sprawiedliwego? W żadnym wypadku. Dlaczego? Ponieważ nagroda za wolny wybór odbierana jest przez konieczność. Powiedz mi, czy jeśli ktoś

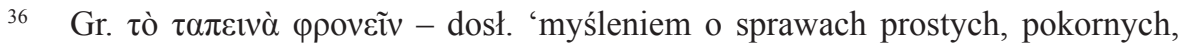
małych'.

37 Chodzi tu o zdolność, możliwość związaną z osobowością, przymiotem, cechą charakteru, sprzyjające warunki, okoliczności. 
nie ma możliwości, by zostać tyranem ${ }^{38}$ bądź królem i pozostaje zwykłym obywatelem, to powinniśmy uznać go za bezczynnego? ${ }^{39}$ Skądże, podobnie jak przy poprzednim przykładzie. Uznanie [za godnego nagrody], o wy nierozumni, nie zależy od powstrzymania się od tego, lecz od pełnienia dobrych uczynków. Ten [który się powstrzymał] uwolnił się od nagany, lecz nie uczestniczy jeszcze w nagrodzie - [chociaż] i to już jest godne pochwały. Spójrz, że i Chrystus w ten sposób nagradza, kiedy mówi: „Pójdźcie, błogosławieni Ojca mojego, weźcie w posiadanie królestwo przygotowane wam od założenia świata! Bo byłem głodny, a daliście mi jeść; byłem spragniony, a daliście mi pić" (Mt 25,34-35). Nie powiedział - ponieważ nie byliście chciwi ani ponieważ nie kradliście (to są bowiem drobne sprawy), lecz ponieważ widzieliście, że byłem głodny i daliście mi jeść. Czy ktoś kiedykolwiek wychwalałby swoich przyjaciół czy wrogów w ten sposób? Nikt, nawet Paweł. Dlaczego mówię o Pawle? Nikt nie chwalił żadnego człowieka, jak ty [Pawle] chwalisz Chrystusa, ponieważ nie przyjął on należnej sobie władzy. Dziwienie się temu jest świadectwem wielkiego zła. Dlaczego? Ponieważ u nich [tych, którzy się temu dziwią] już to jest godne nagrody, że ten, „który [kiedyś] kradł, przestał kraść” (Ef 4,28). Nie tak jest natomiast u dobrych ludzi. Bo czy jest godny pochwały człowiek, który nie przyjął władzy i zaszczytów będących poza jego możliwością? Jak wielka to głupota! Poza tym (uważajcie, proszę, to bowiem rozumowanie jest skomplikowane), czy ktoś kogokolwiek zachęcał do pokory w ten sposób? Przykłady bowiem dotyczące postępowania, do którego zachęcamy, muszą być wyraźniejsze niż ono samo, gdyż nie jest tak, żeby ktoś był poruszony przez coś mu niezrozumiałego. Podobnie też Chrystus namawiał nas do czynienia dobra naszym nieprzyjaciołom, podając za wielki przykład swego Ojca: ,ponieważ On sprawia, że Jego słońce wschodzi nad złymi i nad dobrymi, i On zsyła deszcz na sprawiedliwych i niesprawiedliwych" (Mt 5,45). Namawiał także do cierpliwości w znoszeniu zła, podając za przykład samego siebie: „Uczcie się ode mnie, bo jestem cichy i pokorny sercem” (Mt 11,29). I znowu: „Jeśli Ja, wasz Pan to uczyniłem, jak bardziej i wy powinniście [to czynić]" (J 13,14). Widzisz, jak te przykłady nie sa dla nas odległe? Nie ma potrzeby, aby przykłady były wyszukane, chodzi o to, aby były dla nas wiarygodne. Lecz w tym fragmencie jest odwrotnie - przykład nie jest nam bliski. Dlaczego? Ponieważ [Chrystus] jest przedstawiony jako sługa, jest także mniejszy i jest poddany temu, który jest większy. Właśnie dlatego nie jest to pokora. Należało uczynić przeciwnie: wskazać kogoś większego, który stał się posłuszny mniejszemu. A jeśli [Paweł] nie wykazał tego w przypadku Boga [rozróżnienia na mniejszego

38 Słowo ,tyran” nie implikuje tu negatywnego znaczenia.

39 Gr. $\alpha \pi \rho \alpha ́ \gamma \mu o v \alpha$ - dosł. '[uznać] za niezaangażowanego'. 
i większego], to przyjął, że są równi. Jeśli Syn byłby mniejszy, to nie mógłby być dla nas dostatecznym przykładem pokory. Dlaczego? Ponieważ nie jest pokorą, gdy mniejszy nie powstaje przeciw większemu oraz gdy nie próbuje przejąć władzy, lecz gdy jest posłuszny aż do śmierci.

Następnie spójrz, co mówi po podaniu tego przykładu: ,lecz w pokorze oceniając jedni drugich za wyżej stojących od siebie" (Flp 2,3). Oceniając, powiada: skoro jesteście jednym pod względem substancji i godności, która pochodzi od Boga, należy, aby [wasze] wzajemne oceny były tożsame. Nie powiedziałby „oceniając” w sprawie, kto jest większy, a kto mniejszy, lecz [powiedział]: szanujcie się, uznając się wzajemnie za lepszych od siebie. Podobnie jak w innym miejscu [Paweł] powiedział: „Bądźcie posłuszni waszym przełożonym i bądźcie im ulegli" (Hbr 13,17). Tam posłuszeństwo wynika z natury tej relacji, tutaj natomiast powinno wynikać z naszej własnej oceny. „W pokorze - mówi - oceniając jedni drugich za wyżej stojących od siebie", tak jak czynił Chrystus. W ten sposób ich [heretyków] thumaczenia zostają obalone. Trzeba zatem, abym mówił o nas później, po uprzednim podsumowaniu heretyków. Paweł, nawołując do pokory, nie przedstawiał mniejszego jako posłusznego większemu. Jeśli bowiem zachęcał sługi, aby byli posłuszni swoim panom, czynił to właściwie. Jeśli jednak nawoływał wolnych do posłuszeństwa wolnym, w jakim celu przedstawiał poddanie się sługi swojemu panu? Temu, który jest mniejszy, większemu? Nie mówi przecież „wy, którzy jesteście mniejsi, poddajcie się większym”, lecz wy, którzy macie tę samą godność, nawzajem bądźcie sobie posłuszni, „oceniając jedni drugich za wyżej stojących od siebie". Dlaczego więc nawet nie przywołał posłuszeństwa żony, mówiąc, że skoro żona słucha męża, to i wy bądźcie dla siebie posłuszni? Zatem jeśli nie przywołał tego stwierdzenia w przypadku, w którym jest wolność i równość, w którym co prawda występuje podporządkowanie, choć niewielkie, w jak mniejszym stopniu mógłby odnieść to poddanie do niewolnika? Powiedziałem już, że nikt nie powinien chwalić człowieka za powstrzymanie się od zła, nawet niech o tym nie wspomina. Nikt, kto pragnąłby pochwalić kogoś za wstrzemięźliwość, nie powiedziałby: „nie popełnił cudzołóstwa”, ale powiedziałby: „powstrzymuje się od obcowania z własną żoną”. Nie uznajemy bowiem powstrzymywania się od zła za godnego chwały - byłoby to wówczas niedorzeczne. Powiedziałem, że postać sługi jest prawdziwa i nie mniejsza. Tak więc postać Boga jest doskonała, nie mniejsza. Dlatego też nie powiedział: powstając z postaci Boga, lecz ,istniejąc”. To samo przekazał, mówiąc: „Jestem, który jestem” (Wj 3,14). Postać wskazuje na niezmienność, dopóki jest postacią. Nie jest możliwe, aby będąc $\mathrm{z}$ innej substancji, mieć inną postać. Podobnie jak żaden człowiek nie może mieć postaci anioła, tak też żadne zwierzę nie może przyjąć postaci człowieka. W jaki sposób 
mógł uczynić to Syn? W naszym przypadku, ponieważ natura ludzka jest złożona, postać przynależy do ciała. W kwestii prostej i niezłożonej natury natomiast bez wątpienia postać odnosi się do substancji. I jeśli twierdzisz, że [Paweł] nie wskazuje na Ojca, ponieważ powiedział to bez rodzajnika, dostrzeżesz także, że i w wielu innych miejscach go nie używa. Dlaczego mówię w wielu innych miejscach? Przecież właśnie w tym miejscu mówi [Paweł]: „wiedział, że Jego bycie równym Bogu nie jest zawłaszczeniem”, nie używając rodzajnika, chociaż mówi właśnie o Bogu Ojcu. Chciałbym jeszcze dodać coś od siebie, lecz boję się, że przytłoczę wasze umysły. Tymczasem pamiętajcie o tym, co zostało obalone. Lecz teraz wykorzeńmy ciernie, by następnie rozsypać dobre nasienie, dzięki któremu ziemia dozna odrobiny wytchnienia. Wtedy zniknie stąd wszelkie zło, a ziemia otrzyma boskie nasienie wielkiej cnoty. Podziękujmy Bogu za to, co powiedział. Błagajmy, aby nas strzegł i chronił przed nimi [heretykami], abyśmy zarówno my, jak i wy radowali się wspólnie, a heretycy odczuwali wstyd. Prośmy, aby otworzył nasze usta na tych, którzy będą za nami podążali, abyśmy $z$ wielką gorliwością trwali w wierze.

Błagajmy [Boga], żeby dał nam życie godne wiary i abyśmy żyli dla jego chwały oraz aby jego imię nie zostało przez nas znieważone. „Biada wam”, powiada, ,przez których imię Boga zostanie znieważone” (por. Iz 52,5). Jeśli bowiem mielibyśmy syna (a któż mógłby być nam bliższy niż syn?), jeśli więc mielibyśmy syna, przez którego zostalibyśmy znieważeni, zrzeklibyśmy się i odwrócili od niego, nie przyjmując go z powrotem. Jak tym bardziej Bóg, który ma niewdzięczne sługi, którzy go obrażają i znieważają, mógłby się od nich nie odwrócić i ich nie znienawidzić? A kto bowiem zająłby się tym, którego Bóg odrzucił i znienawidził? Nikt, chyba że szatan albo demony. A jeśli kimś zawładną demony, jaka pozostaje dla niego nadzieja na zbawienie? Jakie pocieszenie w życiu? Dopóki pozostajemy w rękach Boga, nikt nie jest w stanie nas z nich wyrwać (J 10,28), są one bowiem silne. Lecz jeśli wypadniemy z jego rąk i odrzucimy jego pomoc, zginiemy, będziemy narażeni przez wszystkich na nękanie i pogardę „jak ściana pochylona, jak mur, który się wali” (Ps 62,3). Ponieważ kiedy mury są słabe, łatwo je pokonać. Nie sądźcie, że to, co zamierzam powiedzieć, odnosi się tylko do Jerozolimy - przeciwnie, dotyczy to każdego człowieka. Co zatem zostało powiedziane o Jerozolimie? „Chcę zaśpiewać memu Przyjacielowi pieśń o Jego miłości ku swojej winnicy! Przyjaciel mój miał winnicę na żyznym pagórku. Otóż okopał ją i oczyścił z kamieni, i zasadził w niej szlachetną winorośl; pośrodku niej zbudował wieżę, także i tłocznię w niej wykuł. I spodziewał się, że wyda winogrona, lecz ona cierpkie wydała jagody. «Teraz więc, o mieszkańcy Jeruzalem i mężowie z Judy, rozsądźcie, proszę, między Mną a między winnicą moją. Co jeszcze 
miałem uczynić winnicy mojej, a nie uczyniłem w niej? Czemu, gdy czekałem, by winogrona wydała, ona cierpkie dała jagody? Więc dobrze! Pokażę wam, co uczynię winnicy mojej: rozbiorę jej żywopłot, by ją rozgrabiono; rozwalę jej ogrodzenie, by ją stratowano. Zamienię ją w pustynię, nie będzie przycinana ni plewiona, tak iż wzejdą osty i ciernie. Chmurom zakażę spuszczać na nią deszcz». Otóż winnicą Pana Zastępów jest dom Izraela, a ludzie z Judy - szczepem Jego wybranym. Oczekiwał On tam sprawiedliwości, a oto rozlew krwi i prawowierności, a oto krzyk grozy" (Iz 5,1-7). To zostało powiedziane do każdej duszy. Bo kiedy kochający Bóg uczynił dla człowieka wszystko, co jest mu potrzebne, to on zamiast winogron przyniósł ciernie. Dlatego też [Bóg] rozbierze mu ogrodzenie i zburzy żywopłot, aby go rozgrabiono. Posłuchaj, jak o tej lamentacji mówią inni prorocy: „Dlaczego jej mury zburzyłeś, tak że zrywa z niej [grona] każdy, kto przechodzi drogą, że ją niszczy dzik leśny, a polne zwierzęta obgryzają?" (Ps 80,13-14). Wtedy bowiem rzecz dotyczyła Medów i Babilończyków. Teraz [Bóg] nie mówi o nich, lecz o dziku i zwierzęciu, którym jest szatan, i o wszystkim tym, co leży w jego mocy. Przywołuje tu dzika z uwagi na jego zuchwałość i nieczystość. Bo gdy chciał pokazać jego zuchwałość za pomocą słów, powiedział: „diabeł jak lew ryczący krąży, szukając, kogo pożreć” (1P 5,8). Kiedy chce wykazać jego jadowitość, skłonność do zguby, nazywa go wężem i skorpionem: „Stąpajcie - powiada - po wężach i skorpionach, i po całej potędze przeciwnika, a nic wam nie zaszkodzi" (Łk 10,19). Kiedy z kolei chce pokazać jego siłę oraz jad, nazywa go smokiem, mówiąc: „Lewiatan, którego stworzyłeś na to, aby w nim igrał” (Ps 104,26). [Pisma] nazywają wszędzie smoka wykrzywionym wężem i żmiją. Jest to zwierzę wykręcone w różne strony i zmienne: wszystko porusza, we wszystkim powoduje zamęt. Lecz nie bójcie się i nie traćcie ducha, czuwacie jedynie, a on będzie jak wróbelek. „Stąpajcie - powiada - po wężach i skorpionach". Jeśli bowiem zechcemy, podeptamy szatana z mocy Boga naszymi stopami. Spostrzegasz zatem, jakie to śmieszne albo raczej jakie żałosne widzieć tego, który został nam dany, abyśmy po nim stąpali, a który stoi ponad naszymi głowami? Jak to się stało? Przez nas. Jeśli chcemy, [szatan] staje się wielki; jeśli chcemy - staje się mały. Jeśli troszczymy się o siebie, trwając przy tym, który jest naszym Bogiem, szatan będzie malał, a w prowadzonej przeciwko nam wojnie będzie jak małe dziecko. Kiedy natomiast odstępujemy od Boga, on znacznie wzrasta, ryczy i ostrzy kły, ponieważ znalazł nas pozbawionych największej pomocy. Nie zbliży się do nas, jeśli Bóg na to nie pozwoli. Jeśli nie odważył się wejść do wnętrza świni bez pozwolenia Boga, o ile bardziej obawiałby się zniewolić duszę człowieka. Lecz Bóg na to pozwala, czy to by nauczyć, czy to aby ukarać, czy też po to, aby wypróbować, jak w przypadku Hioba. Widzisz, że szatan 
nie przyszedł do Hioba, nie odważył się nawet zbliżyć, lecz drżał i bał się? Ale dlaczego mówię o Hiobie? Atakując Judasza, nie odważył się zawładnąć nim całkowicie ani też wejść w niego, dopóki Chrystus nie wyłączył go [Judasza] z grona ${ }^{40}$ swych uczniów. Wtedy zaatakował go z zewnątrz, do wewnątrz natomiast nie odważył się wejść. Skoro jednak spostrzegł, że Judasz został odłączony od świętego grona, wtargną $\mathrm{z}$ gwałtownością większą niż u wilka i nie opuścił go, dopóki ten nie zginął podwójną śmier$\mathrm{cią}^{41}$. Zostało to napisane, aby nas przestrzec.

Jaki zatem zysk mamy z wiedzy, że jeden z dwunastu zdradził? Jaką korzyść? Jaką pomoc? Wielką. Ponieważ kiedy będziemy wiedzieli, skąd bierze się ten zgubny zamiar, wówczas będziemy mieli się na baczności, abyśmy przez niego nie cierpieli. Skąd wziął się ów zamiar? Z chciwości Judasz był złodziejem. Będąc tak upojonym tą żądzą, zdradził swego Pana świata za trzydzieści srebrników. Co może być gorszego od takiego szaleństwa? Tego, któremu nic nie jest równe, wobec którego narody są niczym (por. Iz 40,15), tego zdradził za trzydzieści srebrników. Chciwość jest ciężkim zniewoleniem, okazuje się okrutna, gdy zawładnie duszą. Nie w takim stopniu ktoś staje się szaleńcem przez pijaństwo jak z powodu chciwości. Nie przez szał i obłęd, lecz przez miłość do pieniędzy.

Dlaczego, powiedz mi [Judaszu], zdradziłeś Chrystusa? Powołał ciebie, człowieka nieznanego i nieznaczącego i uczynił jednym z dwunastu. Podzielił się z tobą swoją nauką, obiecał ci tysiąc dobrych rzeczy, uzdolnił do czynienia cudów, jadał z tobą przy tym samym stole. Pokonywaliście te same drogi, żyliście w tej samej wspólnocie i współdzieliliście resztę spraw. Czy te wszystkie rzeczy nie były wystarczające, aby cię powstrzymać? $\mathrm{Z}$ jakiego powodu go zdradziłeś? Mając to wszystko, dlaczego go oskarżyłeś, niegodziwcze? Czego dobrego nie otrzymałeś z jego rąk? On znał twoje zamiary i nie powstrzymał cię przed ich wykonaniem. Wielokrotnie mówił: „Jeden z was mnie zdradzi” (Mt 26,21). Często cię ganił, jednak nie odtrącił; chociaż wiedział, że to ty go zdradzisz, nie wyłączył cię z grona swych uczniów. Wciąż zabierał cię ze sobą, ciągle uważał za ucznia, za jednego $z$ dwunastu, tak bardzo cię kochał i szanował. Wreszcie, niegodziwcze, zabrawszy prześcieradło, umył swoimi czystymi rękoma twe brudne stopy, i nawet to cię nie powstrzymało. Ukradłeś to, co należało do biednych i abyś nie popełnił większego zła, zniósł także i to. Lecz nic cię nie przekonało. Jeślibyś nawet był dzikim zwierzęciem albo kamieniem, czy nie zmieniłyby cię dobre czyny kierowane ku tobie, te cuda, to nauczanie? I chociaż byłeś niczym dzikie zwierzę, wciąż cię wołał i przez niezwykłe uczynki skłaniał ku sobie, ciebie, bardziej niewrażliwego od kamieni.

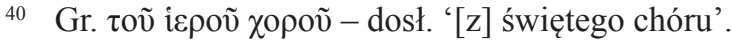

41 Podwójną śmiercią, tj. duchową i cielesną.
} 
I żadna z tych rzeczy nie mogła sprawić, abyś stał się lepszy. Być może dziwi was tak wielki obłęd zdrajcy. Stąd lękajcie się tego, co go zraniło: stał się taki z chciwości, z miłości do pieniędzy. Porzuć tę żądzę, ona bowiem rodzi takie choroby, czyni nas bezbożnymi, sprawia, że nie dostrzegamy Boga, choćbyśmy nawet otrzymali od niego dziesięć tysięcy dóbr. Błagam, porzuć ją - nie jest [chciwość] zwykłą chorobą, lecz taką, która wie, jak zrodzić tysiąc okrutnych śmierci. Widzieliśmy cierpienie Judasza. Bójmy się, aby ono nas nie spotkało. Dlatego jest napisane, abyśmy nie doświadczyli tego zła co on. $Z$ tego powodu też wszyscy ewangeliści zwracają uwagę na chciwość Judasza, aby nauczyć nas roztropności. Uciekaj od niej daleko. Chciwość to nie tylko pragnienie posiadania wielu pieniędzy, lecz pragnienie posiadania wyłącznie pieniędzy. To okropna rzecz pragnąć więcej, niż się potrzebuje. Czy to złote talenty przekonały zdrajcę? Nie, było to trzydzieści srebrników - trzydzieści srebrników za zdradę Pana. Czy pamiętacie, jak mówiłem wcześniej, że chciwość ujawnia się nie w żądzy posiadania wielu bogactw, lecz w ciągłym przyjmowaniu tego, co małe? Widzisz bowiem, jak wielkie zło popełnił dla niewielkiej ilości złota - co więcej - nie dla złota, lecz srebra. Nie jest możliwe, naprawdę nie jest możliwe, aby chciwy człowiek kiedykolwiek zobaczył twarz Chrystusa. Jest to jedna z rzeczy, które nigdy się nie staną. Chciwość jest źródłem zła. A zatem jeśli ktoś uległ temu złu, nosząc w sobie jego źródło, to nie dostąpi chwały, w której miał mieć udział? Nie jest możliwe, aby sługa pieniędzy był prawdziwym sługą Chrystusa. Chrystus sam oświadczył, że to niemożliwe: „nie będziesz służył Bogu i mamonie”, a także: „nikt nie może dwom panom służyć" (Mt 6,24). Sprzeczne bowiem są ich [Chrystusa i Mamony] pouczenia. Chrystus powiada: „Miejcie wzgląd na ubogich”, Mamona natomiast: „Nagim zabierz to, co mają”. Chrystus mówi: „,Rozdaj, cokolwiek posiadasz”, Mamona zaś: „Zabierz, cokolwiek posiadają”.

Dostrzegasz tę sprzeczność, dostrzegasz tę walkę? Chcielibyście, abym wykazał, jak to możliwe, że człowiek nie może z łatwością być posłuszny obu, tylko należy, aby jedno odrzucił? Czy to naprawdę wymaga wyjaśnienia? Więc jak to możliwe? Czyż nie dostrzegamy, że pogardzając Chrystusem, czcimy mamonę? Czy nie rozumiecie, jak te słowa są bolesne? A tym samym o ile bardziej bolesny jest sam czyn? Wprawdzie, skoro jesteśmy owładnięci chorobą, czyny te w rzeczywistości nie wydają nam się aż tak bolesne. Teraz bowiem, kiedy dusza nie jest całkowicie czysta z powodu choroby, to dopóki się nie oczyści, nie może oceniać właściwie. Kiedy bowiem [dusza] odchodzi [od Chrystusa] i zostaje opanowana przez gorączkę oraz samą przyjemność rzeczy, nie może postrzegać w sposób czysty ani też osądzać pokornie. Chrystus mówi: „Tak więc nikt z was, kto nie wyrzeka się wszystkiego, co posiada, nie może być moim uczniem" 
(Łk 14,33). Mamona mówi: „Zabierz chleb ubogim”, Chrystus powiada: „Przyodziej nagich”, ta rzecze: „Rozbierz nagich”, Chrystus: „Nie odwracaj się od swoich bliźnich” (por. Iz 58,7). Mamona powie: „Nie lituj się nad swoimi bliźnimi, lecz jeśli widzisz matkę swoją czy ojca [w niedostatku], pogardź nimi”. Dlaczego mówię „matkę czy ojca”? Zniszcz nawet swoją własną duszę. I [człowiek] jest jej posłuszny. Niestety! Ten, który rozkazuje w sposób srogi i okrutny, zostaje usłuchany bardziej niż ten, który czyni to $\mathrm{w}$ sposób łagodny i zbawienny. $\mathrm{Z}$ tego ma swój początek piekło, $\mathrm{z}$ tego ogień, z tego rzeka ognia, $\mathrm{z}$ tego wiecznie żyjący robak.

Wiem, że kiedy o tym wspominam, jest wielu słuchaczy, którym [mowa ta] nie sprawia przyjemności. Także i dla mnie te słowa nie są przyjemne. Lecz po co należy o tym mówić? Chciałbym móc zawsze opowiadać o tym, co dotyczy Królestwa: o odpoczynku, o wodach przynoszących spokój, o zielonych pastwiskach, bo [Pan]: „Pozwala mi leżeć na zielonych pastwiskach, prowadzi mnie nad wody, gdzie mogę odpoczać" (Ps 23,2). Chciałbym mówić o tym miejscu, gdzie nie ma bólu, choroby, lęku. Chciałbym opowiadać o przyjemności, jaka wypływa ze wspólnoty z Chrystusem, która przewyższa każde słowo i każde poznanie. Chciałbym mówić o tym z całych sił. Lecz co mam zrobić? Nie jest możliwe mówić o Królestwie temu, który źle się ma i gorączkuje. Wówczas należy mówić o zdrowiu. Nie jest możliwe, aby mówić o honorze wobec tego, który stoi przed sądem i którego pragnieniem jest, aby został uwolniony od kary i wyroku. Jeśli to się nie dokona, jak może dokonać się tamto? ${ }^{42}$ Dlatego nieustannie mówię o tych rzeczach, abyśmy szybciej mogli przejść do kolejnych. $Z$ tego powodu Bóg groził piekłem, aby nikt tam się nie dostał i abyśmy podążali w stronę królestwa. Dlatego też i ja wciąż wspominam o piekle, aby was pobudzić do podążania w kierunku Królestwa, aby przestrzec wasze uśpione umysły i przygotować was, abyście postępowali w sposób godny królestwa.

Nie bądźcie zrozpaczeni z powodu srogości tych słów, ponieważ ich srogość oddala od naszych lekkich dusz ciężar grzechów. Bo żelazo jest ciężkie i młot jest ciężki, ale oba tworzą złote oraz srebrne przydatne naczynia, a także prostują te, które są krzywe. Jeśli nie byłyby ciężkie, nie mogłyby służyć do prostowania rzeczy, które są skrzywione. Podobnie i nasze słowa porządkują duszę swoją siłą. Obyśmy nie uciekali przed ciężarem tych słów ani przed ich uderzeniami. Ponieważ są nie po to, aby załamać czy rozerwać naszą duszę, lecz aby ją wyprostować. Wiem, jak z łaski Bożej uderzyć i jak duży zadać cios, aby nie rozkruszyć, lecz wygładzić, odbudować i oddać Bogu, aby nas uzdrowił i uczynił przygoto-

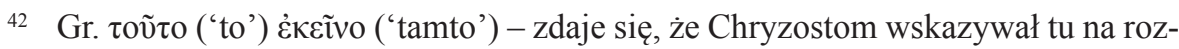
różnienie pomiędzy uzdrowieniem fizycznym (to), a uzdrowieniem duchowym (tamto). 
wanymi na ten dzień, kiedy nadejdzie rzeka ognia. Obyśmy nie wystawili się na ten ogień, bo nieuchronnie spłoniemy, „dzień Pański bowiem ukaże się ogniu" (1Kor 3,13). Lepiej jest, abyście pozwolili poparzyć się przez moje słowa, niż abyście na zawsze płonęli w tym ogniu. I tak rzeczywiście będzie - często dawałem wam ku temu dowody, których nie możecie kwestionować. Już same Pisma powinny was w tym utwierdzić, lecz ponieważ wiele $\mathrm{z}$ nich jest spornych, należy, abyśmy niektóre racje podparli rozumem. Nic nie stoi na przeszkodzie, abyśmy i teraz je przedstawili. Zatem jakie były? „Bóg jest sprawiedliwy”: wszyscy to uznają zarówno Grecy, jak i Żydzi, heretycy i chrześcijanie. Lecz wielu z grzeszników odeszło od tej racji bezkarnie, wielu żyjących cnotliwie natomiast zwątpiło dopiero po przeżyciu tysiąca ciężkich doświadczeń. Więc jeśli Bóg jest sprawiedliwy, gdzie będzie nagradzał, a gdzie wyznaczał pokutę, jeśli nie ma piekła ani nie ma zmartwychwstania?

Tę [rację] powtarzajcie im i sobie nawzajem nieustannie, a to nie pozwoli wam na niewiarę w zmartwychwstanie. Bo kto nie wątpi w zmartwychwstanie, ten będzie z troską i gorliwością dbał o swoje życie, tak aby otrzymać wieczne szczęście, w którym obyśmy wszyscy mieli udział, dzięki łasce i dobroci Pana naszego Jezusa Chrystusa, któremu wraz z Ojcem i Duchem Świętym chwała i cześć, teraz i zawsze, na wieki wieków. Amen.

Z języka greckiego przełożyła oraz opatrzyła wstępem i komentarzem Zofia Latawiec ${ }^{43}$

${ }_{43}$ Doktorantka w Instytucie Filologii Klasycznej na Wydziale Filologii Klasycznej Uniwersytetu Jagiellońskiego, e-mail: zo.latawiec@gmail.com, ORCID: 0000-0001-6643-8062. 